\title{
Chromogranin-A and its role in the pathogenesis of diabetes mellitus
}

\author{
Chromogranina A i jej rola w patogenezie cukrzycy
}

\author{
Zoltan Herold ${ }^{1}$, Marton Doleschall ${ }^{4}$, Annamaria Kovesdi', Attila Patocs ${ }^{2,3}$, Aniko Somogyi $^{1}$ \\ ${ }^{1} 2^{\text {nd }}$ Department of Internal Medicine, Semmelweis University \\ ${ }^{2}$ Department of Laboratory Medicine, Semmelweis University, Hungarian Academy of Sciences and Semmelweis University \\ 3"Momentum" Hereditary Endocrine Tumours Research Group, Hungarian Academy of Sciences and Semmelweis University \\ ${ }^{4}$ Molecular Medicine Research Group, Hungarian Academy of Sciences and Semmelweis University
}

\begin{abstract}
Chromogranin A is a member of the granin glycoprotein family that is expressed by the endocrine and neuroendocrine cells of different organs. Intracellularly, chromogranin A contributes to the regulation of secretion and gives several cleavage products after secretion. Some of its cleavage products modify the hormone functions in autocrine and paracrine ways, while the functions of others have not been fully understood yet.

Serum chromogranin A level is most prominently used in neuroendocrine tumour diagnostics. In addition, recent studies have suggested that chromogranin A and some of its cleavage products (pancreastatin and WE-14) also play important roles in the pathogenesis of the various forms of diabetes mellitus, but their exact mechanisms still need to be clarified.

Higher chromogranin A, pancreastatin, and WE-14 levels have been reported in type 1, type 2, and gestational diabetic patients compared to healthy controls. A notable connection has been inferred through the observation that type 1 diabetes mellitus is not at all or rarely developed in chromogranin A gene-knockout, non-obese diabetic model mice compared to non-knockout, non-obese diabetic mice. Pancreastatin inhibits insulin release in various cell and animal models, and WE-14 serves as an autoantigen for both CD4 ${ }^{+}$and CD8 ${ }^{+}$ beta cell-destructive diabetogenic T-cell clones in type 1 diabetes.

Chromogranin A contributes to the pathogenesis of diabetes mellitus according to the available literature. The current findings facilitate further investigation to unravel the deeper relationships between this glycoprotein and diabetes. (Endokrynol Pol 2018; 69 (5): 598-610)
\end{abstract}

Key words: chromogranin A, diabetes mellitus, diabetes mellitus type 1, diabetes mellitus type 2, gestational diabetes, mice inbred NOD, pancreastatin, WE-14

\section{Streszczenie}

Chromogranina A jest członkiem rodziny glikoprotein granin i występuje w komórkach endokrynnych i neuroendokrynnych różnych organów. Chromogranina A wewnątrzkomórkowo przyczynia się do regulacji wydzielania, również tworzą się liczne produkty jej rozkładu po wydzielaniu. Niektóre produkty rozpadu modyfikują funkcje hormonalne w sposób autokrynny lub parakrynny, a w przypadku innych produktów funkcje te nie są w pełni znane.

Stężenie chromograniny A w surowicy jest używane przede wszystkim w diagnostyce guzów neuroendokrynnych. Co więcej, z ostatnich badań wynika, że chromogranina A oraz niektóre jej produkty rozpadu, takie jak pankreostatyna i WE-14, odgrywają istotną rolę w patogenezie różnych form cukrzycy, choć dokładny mechanizm pozostaje do wyjaśnienia.

Wyższe stężenie chromograniny A, pankreostatyny i WE-14 w porównaniu z grupą kontrolną było wykryte u pacjentów z cukrzycą typu 1, 2 oraz cukrzycą ciążową. Na podstawie obserwacji wyciągnięto ważny wniosek, że cukrzyca typu $1 \mathrm{w}$ ogóle nie lub bardzo rzadko rozwija się u nieotyłych, transgenicznych pozbawionych chromograniny A myszy z cukrzycą w porównaniu z niezmutowanymi, nieotyłymi myszami z cukrzycą.

Pankreostatyna hamuje wydzielanie insuliny w różnorodnych modelach komórkowych oraz zwierzęcych, a WE-14 służy jako autoantygen zarówno dla klonów CD4+ i CD8 ${ }^{+}$limfocytów T niszczących komórki $\beta$ w cukrzycy typu 1.

Według dostępnej literatury, chromogranina A przyczynia się do patogenezy cukrzycy. Obecne ustalenia motywują do dalszych badań, aby wyjaśnić bardziej ścisłe zależności między tą glikoproteiną a cukrzycą. (Endokrynol Pol 2018; 69 (5): 598-610)

Słowa kluczowe: chromogranina A, cukrzyca, cukrzyca typu 1, cukrzyca typu 2, cukrzyca ciążowa, myszy szczepu NOD, pankreostatyna, WE-14

\section{Introduction}

Diabetes mellitus is a complex metabolic disorder with multifactorial aetiology. It is one of the most prevalent diseases in our time, occurring in approximately $8-9 \%$ of the world's population. Its current classification - recently described by the American Diabetes Association [1] - includes several forms: type 1 diabetes mellitus (T1DM), type 2 diabetes mellitus (T2DM), other specific types (for example genetic defect forms, endocrinopathies, diseases of the exocrine pancreas and drug-or chemical-induced 
Table I. Comparison of type 1, type 2, and gestational diabetes

Tabela I. Porównanie cukrzycy typu 1, 2 i cukrzycy ciążowej

\begin{tabular}{|c|c|c|c|}
\hline & Type 1 diabetes mellitus (T1DM) & Type 2 diabetes mellitus (T2DM) & $\begin{array}{l}\text { Gestational diabetes mellitus } \\
\text { (GDM) }\end{array}$ \\
\hline Prevalence & $\sim 10 \%$ of the diabetic patients & $\sim 90 \%$ of the diabetic patients & $\sim 14 \%$ of the pregnancies \\
\hline Age at recognition & Usually young & Usually older & Second trimester of the pregnancy \\
\hline Development (speed, onset) & Fast, acute onset & $\begin{array}{l}\text { Slow, usually when a comorbidity is } \\
\text { recognised }\end{array}$ & Only during routine testing \\
\hline Overweight & Usually no & Often & Often \\
\hline Insulin response & Insulin deficiency & Insulin resistance & Usually insulin resistance \\
\hline Family history & Usually rare & Usually diabetes in family & Usually T2DM in family \\
\hline Pathomechanism & $\begin{array}{l}\text { Autoimmune destruction of the } \\
\text { pancreatic beta cells }\end{array}$ & $\begin{array}{l}\text { Insulin resistance and later beta cell } \\
\text { dysfunction }\end{array}$ & $\begin{array}{l}\text { Insulin resistance caused by } \\
\text { hormonal changes of the placenta }\end{array}$ \\
\hline Treatment & Insulin & $\begin{array}{l}\text { Early diagnosis: diet and change of } \\
\text { lifestyle } \\
\text { Late diagnosis: oral antidiabetics and/ } \\
\text { or insulin }\end{array}$ & $\begin{array}{l}\text { First: diet and exercise } \\
\text { If treatment targets are not met in } \\
1-2 \text { weeks: insulin }\end{array}$ \\
\hline Common comorbidities & $\begin{array}{l}\text { Various autoimmune diseases and } \\
\text { mental disorders [141] }\end{array}$ & $\begin{array}{l}\text { Obesity, dyslipidaemia, cardiovascular } \\
\text { events and hypertension, micro- and } \\
\text { macrovascular complications }\end{array}$ & $\begin{array}{l}\text { Mother: Hypertension, pre-eclampsia } \\
\text { Foetus: shoulder dystocia, stillbirth, } \\
\text { hypoglycaemia, higher birthweight }\end{array}$ \\
\hline
\end{tabular}

diabetes forms), and gestational diabetes mellitus (GDM) (Table I) [2-8].

T1DM is caused by the autoimmune destruction of the insulin-producing beta cells in the pancreatic islets and can be characterised by the appearance of various autoantibodies, including islet cell-, glutamic acid decarboxylase-, insulin-, zinc transporter 8-, and islet antigen-2 autoantibodies. T1DM accounts for the majority of young-onset diabetes cases and shows family aggregation, indicating a genetic background. Result from the study of the Type 1 Diabetes Genetics Consortium showed that human leukocyte antigen (HLA) genes represent almost $50 \%$ of the familial risk for developing T1DM, from which HLA class II DR and DQ alleles are the most specific $[9,10]$. Recent results suggest that some environmental factors (for example maternal factors, viral infections, and toxic substances) in genetically predisposed subjects may also play a role in the development of T1DM [9]. The immunemediated pathogenesis in T1DM features islet-specific autoantigens, antigen-specific beta cell-destroying T-cell clones, and the subsequent inflammation of islets. Diabetogenic T-cell clones have been identified both in humans and non-obese diabetic (NOD) mice, the prevailing animal model of T1DM. The early presence of islet autoantigens and diabetogenic T-cell clones prognoses the destruction of the pancreatic beta cells $[4,11-13]$. It was thought for a long time that helper $\mathrm{CD}_{4}{ }^{+} \mathrm{T}$ cells mediate the autoimmune destruction of the pancreatic islets through an interaction with Major Histocompatibility Complex (MHC) class II and
T cell receptors, but the impact of cytotoxic $\mathrm{CD}^{+} \mathrm{T}$ cell clones through MHC class I was later confirmed too [14].

While T1DM has an autoimmune pathomechanism, T2DM is caused by insulin resistance leading to elevated insulin and glucose levels in blood, but a subsequent beta cell dysfunction may develop at a later time. Genetic, epigenetic, and lifestyle factors - such as obesity, lack of physical activity, incorrect quantity and quality of food - contribute to the development of T2DM. The genetic predisposition of T2DM is confirmed by both heritability estimates and twin studies, genome-wide association studies provided a large number of variants that are associated with a higher risk of developing T2DM, and several candidate genes were identified which have been proven to have a relationship to the disease [15]. T2DM is often developed from metabolic syndrome, which is a complex disease including obesity, dyslipidaemia, insulin resistance, and hypertension [16, 17]. The clinical relevance of T2DM is due to its high prevalence and the associated cardiovascular and other complications (such as nephropathy, neuropathy, retinopathy) that can affect patients' quality of life [5, 18, 19].

GDM is caused by insulin resistance due to the hormonal changes of the placenta in pregnant women, and is characterised by elevated blood glucose and slightly increased insulin levels. Environmental factors such as obesity and genetic factors, for example a firstdegree relative who has T2DM, are responsible for its development. GDM endangers both mother and foetus; 
Table II. The available detection methods for chromogranin A. In routine neuroendocrine tumour diagnostics, the most frequently used techniques for detecting chromogranin A from blood samples are RIA and ELISA [25]

Tabela II. Dostępne metody wykrywania chromograniny A. Najczęściej używane techniki detekcji chromograniny A ze krwi w diagnostyce rutynowej guzów neuroendokrynnych to RIA i ELISA [25]

\begin{tabular}{|c|c|c|}
\hline Technique & Type of samples & Comment \\
\hline \multirow{2}{*}{$\begin{array}{l}\text { Radioimmunoassay }{ }^{1,2} \text { (RIA) and immunoradiometric assay }{ }^{1,2} \text { (IRMA) } \\
{[134,135]}\end{array}$} & Serum & \multirow{2}{*}{$\begin{array}{l}\text { Plasma concentrations are significantly highe } \\
{[142,143]}\end{array}$} \\
\hline & Plasma & \\
\hline \multirow[t]{2}{*}{ Enzyme-linked immunosorbent assay, ${ }^{1,2}$ (ELISA) $[137,144]$} & Serum & \multirow{2}{*}{$\begin{array}{l}\text { Used in neuroendocrine tumour diagnostics } \\
\text { routinely }\end{array}$} \\
\hline & Plasma & \\
\hline Time-Resolved Amplified Cryptate Emission (TRACE) $[145,146]$ & Serum & Currently for research only \\
\hline Immunohistochemistry, 2 [147] & Tissue & Used in neuroendocrine tomour diagnostics \\
\hline $\begin{array}{l}\text { Sodium dodecyl sulphate polyacrylamide gel electrophoresis (SDS- } \\
\text { PAGE) and immunoblotting (Western Blot) [136] }\end{array}$ & Saliva & Currently for research only \\
\hline
\end{tabular}

'It is important to emphasise that, in accordance with international recommendations, for proper detection, two-site monoclonal antibody kits (developed by Cisbio) should be used $[25,134-137]$

${ }^{2}$ The usage of antacid medications (e.g. proton pump inhibitors or histamine $\mathrm{H} 2$-receptor antagonists) increase the serum levels of $\mathrm{CgA}$ [138, 139]. Therefore, before measurement it is recommended to suspend these type of treatments, if possible, for at least seven days before the test, to avoid false-positive results [28]. Various diseases, including non-oncological gastrointestinal, cardiovascular, and renal conditions, and several tumour types, may also increase the serum levels [33, 140]

it increases the chance of pre-eclampsia, and it may lead to stillbirth if untreated. In 2017, approximately $14 \%$ of pregnancies were affected by GDM; however, the prevalence can vary in different populations [19]. After birth, GDM is usually resolved, but the risk of developing T2DM later in life is significantly increased [3, 19, 20].

Chromogranin A (CgA) is a 439 amino acid (48kDa)-long protein expressed by the endocrine and neuroendocrine cells of diverse organs. Several cleavage proteins are generated from $\mathrm{CgA}$, some of which have well-known biological activity, while the exact function of others is unclear. The main intracellular function of $\mathrm{CgA}$ is to sort appropriate proteins into secretory granules, while cleavage products act as extracellular regulator molecules. Both the $\mathrm{CgA}$ protein and some of its cleavage proteins - including WE-14, pancreastatin and catestatin - show a relationship to carbohydrate metabolism and have significant involvement in diabetes mellitus [21-26].

$\mathrm{CgA}$ can be detected from serum, plasma, saliva, or tissue samples using different techniques (Table II). It is one of the most prominent secretory products of neuroendocrine tumours, and therefore its serum level is an informative marker to confirm the diagnosis and to monitor the effectiveness of the treatment [27-32]. However, recent studies indicate that its usage may be limited due to various factors: 1 . non-CgA-producing neuroendocrine tumours, 2 . other tumour types may produce $\mathrm{CgA}$ as well, 3 . benign conditions (such as atrophic gastritis or renal dysfunction), and 4. antacid usage may also increase serum CgA levels [33]. Like the whole CgA molecule, WE-14 can also be detected in blood samples [34].
In this review, the available literature on $\mathrm{CgA}$ and its cleavage proteins is discussed, focusing mainly on its biochemistry, distribution, and functions, and its relationships to diabetes and carbohydrate metabolism.

\section{The discovery of chromogranin A and its diabetes-related cleavage products}

Chromogranin A (formerly parathyroid secretory protein 1 or pituitary secretory protein I) is a member of the granin glycoprotein family. It is built from 439 amino acids (48kDa) [21]. The name 'chromogranin' originates from 1967 when Blashko et. al. isolated soluble proteins from bovine chromaffin granules [35, 36], and the first identified protein was named "chromogranin A" [37].

Nearly half of the hormone peptides of mammals have an amide structure at their C-terminal end for biological activity. To identify peptides containing this alphaamide structure, an enzymatic release method, which includes thin layer chromatography, was developed. With this method, a large variety of peptides - often without knowing their exact function - were identified [38]. In 1986, from porcine pancreas, a 49 amino acid-long peptide was isolated that was able to inhibit glucosestimulated insulin secretion. It was named pancreastatin (PST). After the protein's exact sequence was available, several publications appeared indicating that PST closely resembles some parts of bovine $\mathrm{CgA}$. The relationship between the two proteins was confirmed in 1988, when the complete DNA sequence of the porcine CgA gene, including the full-length PST sequence, was published $[38,39]$. This was the first evidence that hormone-like proteins are formed from CgA $[38,40]$. 
WE-14 (the abbreviation comes from N- and Cterminal amino acids and the length of the molecule) was isolated first from human metastatic hepatic cells originating from an ileal carcinoid tumour in 1992 [41], and also proved to be a CgA cleavage product. The peptide was later isolated from human, bovine, and NOD mouse pancreatic beta cells, flask-shaped endocrine cells of intestinal crypts, and porcine adrenal chromaffin cells [11, 42, 43].

In the late 1980s, it was reported that CgA has a cleavage product that can inhibit the nicotine-stimulated catecholamine secretion from cultured adrenal medullary chromaffin cells, but all attempts to identify the active peptide failed until 1997 [44]. The cleaved CgA sections could inhibit significantly more catecholamines than the high molecular weight $\mathrm{CgA}$. To identify the responsible domain within $\mathrm{CgA}$, synthetic CgA-fragments were used to identify the exact cleavage site. The final 20 amino acid-long CgA-fragment was named, after its function, as catestatin (CST). In vivo detection was reported a few years later [45].

\section{Biological properties of chromogranin A}

The human CgA gene (CHGA) spans 12 kilobases at q32.12 locus of chromosome 14 and contains eight exons [46-48]. The genes of vertebrate $\mathrm{CgA}$ and chromogranin B $(\mathrm{CgB})$, a related member of the granin protein family, belong to two related monophyletic groups, which probably diverged from each other before ancestral fish. In all vertebrate species, $\mathrm{CgA}$ contains a large number of glutamic acid, aspartic acid, and hydrophilic proline residues $(21 \%, 4 \%$ and $10 \%$ in humans), resulting in its acidic and hydrophilic properties [21, 49]. Several regions of $\mathrm{CgA}$, being relatively conserved, exhibit similarities to the calcium-binding domains of well-known calcium-binding proteins such as calmodulin or the vitamin D-dependent calcium-binding protein [50-52]. Two cysteine residues at the N-terminus, which together form a disulphide loop after posttranslational modification, are a common structural characteristic of $\mathrm{CgA}$ and $\mathrm{CgB}$ in mammals [21, 53-56]. The WE-14 sequence is conserved during evolution, whereas PST and CST have no conserved homologous sequence in non-mammalian CgA proteins, indicating an ancient function of the former, and novel functions related to the latter [57]. These evolutionary patterns of different structural elements of $\mathrm{CgA}$ indicate that the intracellular sorting function related to acidic, hydrophilic, and calcium-binding abilities is more ancestral than the majority of the extracellular function related to cleavage products.

Foetal CgA production begins in humans between the $6^{\text {th }}$ and $8^{\text {th }}$ week of pregnancy in the chromaffin progenitor cells of the adrenal primordia and the gastrointestinal endocrine cells in stomach, proximal small intestine, distal colon, and rectum [58-61]. In adults, CgA is most abundantly produced by the chromaffin cells of adrenal medulla and the intrinsic neurons of enteric nervous system in the gastrointestinal tract. The presence of $\mathrm{CgA}$ can also be detected in the gastrin-producing, the enterochromaffin, and the enterochromaffin-like cells of the stomach, and the glucagon-producing alpha and insulin-producing beta cells of pancreatic islets. CgA-producing neurons reside in the central and other part of peripheral nervous systems such as the postganglionic neurons of the autonomic nervous system, the thyroid-stimulating, luteinising, follicle-stimulating, and growth hormone-producing endocrine cells of the anterior pituitary gland. The calcitonin-producing C-cells of the parathyroid glands also expressed CgA. Moreover, the neuroendocrine cells in lungs, spleen, prostate and thymus, atrial and ventricular cardiomyocytes, wound keratinocytes, the serous cells and ductal cells of salivary glands, germinal epithelial cells, and polymorphonuclear neutrophils also have CgA expression [23, 24, 49, 62-66].

Many extracellular signalling molecules can influence the expression of $\mathrm{CgA}$. Both secretin and gastrin induce CgA transcription $[67,68]$, while oestradiol inhibits it in the pituitary gland $[69,70]$, and somatostatin diminishes the circadian rhythm of CgA in blood [71]. The receptors of gastrin and secretin are mainly expressed in the areas of the gastrointestinal tract and pancreas, but chromaffin cells are also responsive to secretin. Signal transduction pathways of protein kinases and extracellular signal-regulated kinases mediate gastrin and secretin extracellular signals via the cAMP response element in the $\mathrm{CgA}$ promoter $[67,68,72,73]$.

The CgA protein itself is synthesised in the rough endoplasmic reticulum and then transported to the Golgi apparatus. Inside the trans-Golgi network, CgA accumulates in the newly emerging secretory granules [74]. CgA has a high-capacity and low-affinity calcium binding function, which is primarily regulated by the more acidic $\mathrm{pH}$ levels inside the maturing secretory granules. The increasing $\mathrm{H}^{+}$- and $\mathrm{Ca}^{2+}$ ion concentrations inside the granules can lead to conformational changes in the protein $[75,76] . \mathrm{Ca}^{2+}$ can also enhance the capability of CgA to adhere to membrane [77]. Due to its calcium binding characteristics, after the binding of certain peptide hormones and neurotransmitters, $\mathrm{CgA}$ is able to selectively sort and pack these peptides into secretory granules [51, 78]. In Golgi cisterns $\mathrm{pH}$ is normally neutral, but the influx of $\mathrm{H}^{+}$ions leads to an acidic $\mathrm{pH}$; therefore, the acidic $\mathrm{pH}$-shift induces the aggregation of $\mathrm{CgA}$ and its bound peptides into secretory granules. Following the aggregation, the proteins are 
locked inside the secretory granules when it detaches from the Golgi apparatus. Non-CgA-bounded peptides and proteins are not included in these granules [54, 75, 79-81].

In parallel with protein and peptide sorting, the posttranslational modification of $\mathrm{CgA}$ include glycosylation [82], phosphorylation [83], sulphation [84], carboxymethylation [85], pyroglutamylation [86], the formation of disulphide bonds, two-step proteolytic processing [87-89], and alpha-amidation [38, 90, 91], occurs intracellularly in trans-Golgi network and secretory granules. Biologically active peptides with diverse functions are generated from CgA protein by the cleavage and the subsequent alpha-amidation (Figure 1, Table III). The in vivo isolated cleavage products of $\mathrm{CgA}$ in humans include vasostatin-1 and -2, PST, WE-14, cateslytin, and CST $[25,26,81]$.

Proprotein convertases $1 / 3$ and 2 (PC1/3 and PC2) are considered as the main enzymes performing the first step of proteolytic processing before secretion [87]. They are intracellular, Ca-activated serine endoproteases with acidic $\mathrm{pH}$ optima, and are ubiquitously expressed in endocrine and neuroendocrine cells, features that are logically suited to their localisation and function [92]. Besides CgA, other proproteins such as proinsulin, proglucagon, and proopiomelanocortin are also processed by PC1/3 and PC2. Cathepsin L1 is a lysosomal cysteine endoprotease that mainly contributes to intracellular protein catabolism, but cathepsin L1 in vivo colocalises with CgA in the secretory granules of primary chromaffin cells, and CgA can be a substrate for cathepsin L1 both in vitro and in cella [88]. During the second step of the proteolytic process, carboxypeptidases E and/or D remove the $\mathrm{C}$-terminal, basic amino acid residues after the proteolytic cleavage by $\mathrm{PC} 1 / 3$ and PC2, whereas Arg/Lys aminopeptidase is required to remove the $\mathrm{N}$-terminal basic amino acid residues after the cleavage by cathepsin L1 [89]. After the proteolytic processing, the alpha-amidation of some CgA cleavage products (required for their full biological activity) is catalysed by peptidylglycine alpha-amidating monooxygenase, which is also localised in the trans-Golgi network and secretory granules of endocrine and neuroendocrine cells [93].

About $50 \%$ of $\mathrm{CgA}$ molecules are proteolytically processed in chromaffin cells before secretion [94], and the further extracellular cleavage of CgA may occur. Chromaffin cells express the components of the serine endoprotease plasmin system: thus plasmin is present in the local environment of the chromaffin cells, and extracellularly cleaves $\mathrm{CgA}$ to generate a bioactive product overlapping with CST $[95,96]$. Furthermore, plasmin and the serine endoprotease thrombin can also cleave $\mathrm{CgA}$ in the bloodstream, in addition to

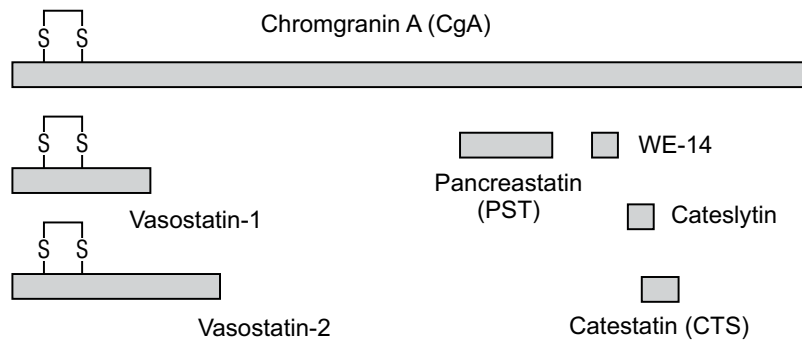

Figure 1. Proportionally scaled chromogranin A protein and its cleavage products isolated from human tissues. A disulphide bridge is located at the $N$-terminal (left) end of the protein. The exact size of cleavage products: vasostatin- $1-C g A_{1-76} ;$ vasostatin-2 $C g A_{1-115^{\prime}}$ pancreastatin $(P S T)-C g A_{250-301 ;} ; W E-14-C g A_{324-337} ;$ cateslytin $-C g A_{344-358^{\prime}}$ catestatin $(C S T)-C g A_{352-372}$

Rycina 1. Proporcjonalnie skalowana proteina chromogranina A oraz produkty rozpadu izolowane z tkanek ludzkich. Mostek dwusiarczkowy znajduje się na N-końcowej (lewej) części białka. Dokładna wielkość produktów rozpadu: wazostatyna-1 $-C g A_{1-76}$; wazostatyna -2 $-C g A_{1-115^{\prime}}$ pankreastatyna $(P S T)-C g A_{250-301 ;}$; WE-14 - Cg $A_{324-337^{\prime}}$ cateslytin $-C g A_{344-358^{\prime}}$ katestatyna (CST) $-\mathrm{Cg} A_{352-372}$

their functions in blood coagulation pathway [97] (Figure 2).

Tissue- and cell-specific distribution of CgA cleavage products has been observed [98-100]. However, there is no information on the underlying differences in intra- and extracellular proteolytic processing. For instance, alpha and beta cells of pancreatic islets have a broad immunoreactivity to $\mathrm{CgA}$ region-specific antibodies, whereas somatostatin-producing delta and pancreatic polypeptide cells show a limited immunoreactivity [99].

\section{The role of chromogranin A in type 1 diabetes mellitus}

Compared to wild type NOD mice, CgA-deficient knockout NOD mice (NOD.ChgA ${ }^{-/}$) do not develop T1DM, or this is observed only in a very small portion of the population, suggesting $\mathrm{CgA}$ is a causative factor of T1DM; during the 12-month observation period T1DM appeared in more than $90 \%$ of the female wildtype NOD mice, while only $3 \%$ of NOD.ChgA ${ }^{-1}$ female mice showed any symptoms of the disease. Male NOD.ChgA ${ }^{-/}$mice had no signs of T1DM at all. Following the 12-month observation period, pathological examinations for insulitis, the inflammation of the pancreatic islets, was performed. Only $20 \%$ of the

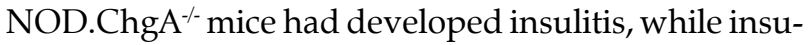
litis was present in all the wild-type NOD mice in both genders, and significantly lower amounts of $\mathrm{CD} 4^{+}$and $\mathrm{CD}^{+} \mathrm{T}$-cells were found in the pancreatic tissues of NOD.ChgA ${ }^{-/}$mice [101]. 
Table III. Functions of the different chromogranin A (CgA) fragments

Tabela III. Funkcje różnych fragmentów chromograniny A (CgA)

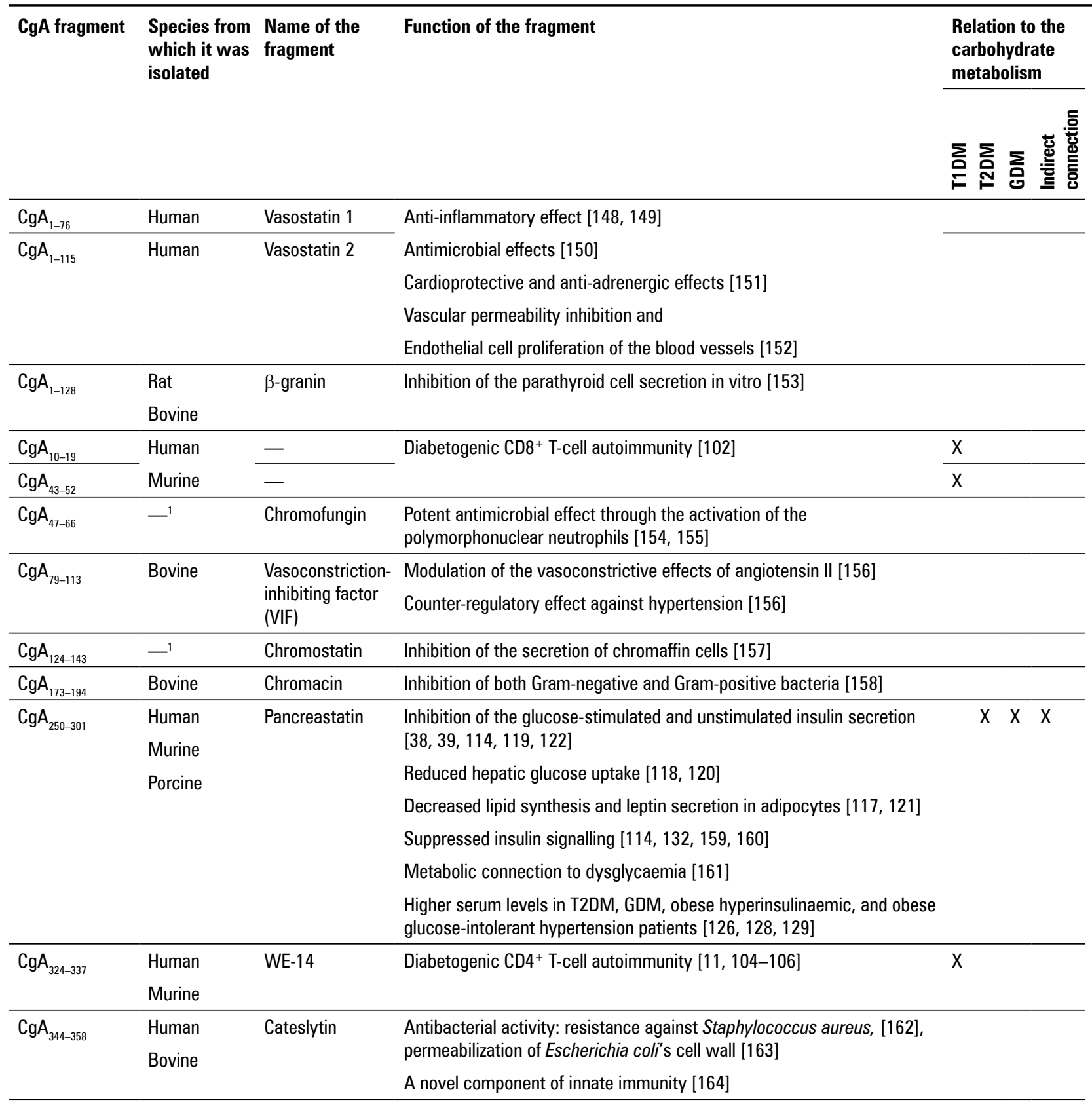

\section{The role of chromogranin A cleavage products in type 1 diabetes mellitus}

Some of the newly-discovered autoantigens of T1DM are the cleavage products of $\mathrm{CgA}$ : WE-14 is known for its $\mathrm{CD}^{+}{ }^{+}$T-cell autoreactivity [11], while other small, $\mathrm{N}$-terminal CgA-fragments have $\mathrm{CD}^{+}$-cell autoimmunity [102].

CgA antigen-specific T cells are selected during the development of the thymus. CgA-specific mRNA is not detectable in embryonical medullary thymic epithelial cells, and this CgA-mRNA deficit may be the cause for the insufficient amount of CgA-reactive T-cell deletion because there is not enough $\mathrm{CgA}$ and/or WE-14 inside the thymus to mediate the deletion $[11,103]$. When analysing the structure of the $\mathrm{CD} 4{ }^{+}$autoreactive WE-14, it was found that despite its common antigen-binding motif, WE-14 is missing the $\mathrm{N}$-terminal amino acids that usually bind easily to the NOD-mouse-specific MHC class II I-A ${ }^{87} \mathrm{p} 1$ and $\mathrm{p} 4$ antigen-binding sites. These are usually necessary for a stable MHC class II binding. It can be assumed that the C-terminus of WE-14 can interact with the MHC class II I-A ${ }^{g 7}$ at a site outside of the normal peptide binding groove [11]. Outside 
Table III (cont.). Functions of the different chromogranin A (CgA) fragments

Tabela III (cd.). Funkcje różnych fragmentów chromograniny A (CgA)

\begin{tabular}{|c|c|c|c|c|c|c|c|}
\hline \multirow[t]{2}{*}{ CgA fragment } & \multirow[t]{2}{*}{$\begin{array}{l}\text { Species from } \\
\text { which it was } \\
\text { isolated }\end{array}$} & \multirow[t]{2}{*}{$\begin{array}{l}\text { Name of the } \\
\text { fragment }\end{array}$} & \multirow[t]{2}{*}{ Function of the fragment } & \multicolumn{4}{|c|}{$\begin{array}{l}\text { Relation to the } \\
\text { carbohydrate } \\
\text { metabolism }\end{array}$} \\
\hline & & & & 主 & 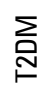 & 方 & 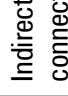 \\
\hline \multirow{10}{*}{$\mathrm{CgA}_{352-372}$} & Human & Catestatin & Decreased plasma concentration in essential hypertension [165] & & & & $\mathrm{X}$ \\
\hline & Murine & & Counter-regulation of the $\beta$-adrenergic and endothelin- 1 stimulated & & & & \\
\hline & Bovine & & action [166] and antiadrenergic effect [167] & & & & \\
\hline & & & Normalisation of baroreflex [132] & & & & \\
\hline & & & Improved insulin sensitivity in catestatin-knockout mice [133] & & & & \\
\hline & & & Induction of angiogenesis [168] & & & & \\
\hline & & & Antimicrobial activity against bacteria, fungi, and yeasts [164] & & & & \\
\hline & & & Antioxidant activity [169] & & & & \\
\hline & & & $\begin{array}{l}\text { Effective catecholamine release inhibition and endogenous nicotinic } \\
\text { cholinergic antagonistic effect }[113,132]\end{array}$ & & & & \\
\hline & & & Obesity-reducing effects [131] & & & & \\
\hline $\mathrm{CgA}_{357-428}$ & Porcine & Parastatin & Inhibition of the low $\mathrm{Ca}^{2+}$-stimulated parathyroid secretion in vitro $[170,171]$ & & & & \\
\hline $\mathrm{CgA}_{367-391}$ & Bovine & GE-25 & No known biological effect so far $[172,173]$ & & & & \\
\hline \multirow[t]{2}{*}{$\mathrm{CgA}_{417-442}$} & Murine & Serpinin & A novel, $\beta$-adrenergic-like cardiac modulator $[174,175]$ & & & & \\
\hline & Rat & & & & & & \\
\hline
\end{tabular}

${ }^{1}$ Synthetic peptides

of pancreatic $\beta$-cells in NOD mice, the CgA-induced $\mathrm{CD}^{+}$autoimmune reactions of other gastro-enteropancreatic tissues were not supported [42]. The observation that the CgA-induced autoimmune reaction is only detectable in the beta cells is still unclear to our present knowledge, although several theories have been proposed [11]: 1 . Selective autoimmune reactivity is caused by a difference in the proteolytic processing of $\mathrm{CgA}$ between beta cells and other cell types of pancreatic islets, or between islet cells and other cells with CgA expression; 2 . WE-14 can only function as a pancreatic autoantigen after pancreas-specific post-translational modifications differing proteolytic processing [11].

The antigenic activity of WE-14 can be dramatically increased when modified by enzyme tissue transglutaminase (TGase) $[104,105]$ or with N-terminal amino acid additions [106]. TGase catalyses the glutamine deamidation of various proteins, changing glutamine to glutamic acid, and covalently crosslinking between the side chains of glutamine and lysine [107]. TGase converts WE-14 from a weak antigen into a potent one for CgA-reactive- and I-A ${ }^{87}$-restricted-CD4 ${ }^{+} \mathrm{T}$ cells [104]. The higher antigenicity of WE-14 is caused by the crosslinking, while the antigenic strength of deamidated WE-14 is similar to the unmodified molecule [34]. While healthy controls appear normal, newly diagnosed T1DM patients have shown elevated WE-14 antigenicity in their blood samples, which can be increased by in vitro TGase treatment. How often these modifications of WE-14 by TGase can occur in the pancreatic beta cells in vivo is currently unknown, but it was suggested that the increased immune response may develop due to aberrant post-translational modifications [105].

Different NOD mouse T-hybridoma cell lines carrying different structural variants of T-cell receptors are responsive to low concentrations of a WE-14 that has been modified with an N-terminal arginine-leucineglycine-leucine addition (RLGL-WE14) in vitro. Reverse proteolysis or transpeptidation mechanisms may play a major role in the generation of RLGL-WE-14, which occur after the cleavage product is cleaved by the proprotein convertases from the original CgA molecule [106].

Human association studies [108-110] and a subsequent animal study with humanised NOD mice verified that the presence of human HLA-A*0201 serotype is an important contributor to the development of T1DM [110]. Samples from HLA-A*0201-positive transgenic NOD mice and onset HLA-A*0201-positive T1DM patients diagnosed within one year showed $\mathrm{CgA}$-fragment-related $\mathrm{CD}^{+}$T-cell autoimmunity [102]. Human $\mathrm{CgA}_{10-19^{\prime}} \mathrm{CgA}_{43-52}$ and murine $\mathrm{mCgA}_{10-19}$ and $\mathrm{mCgA}_{43-52}$ fragments that have been exposed to splenic CD8+ T-cell clones displayed 


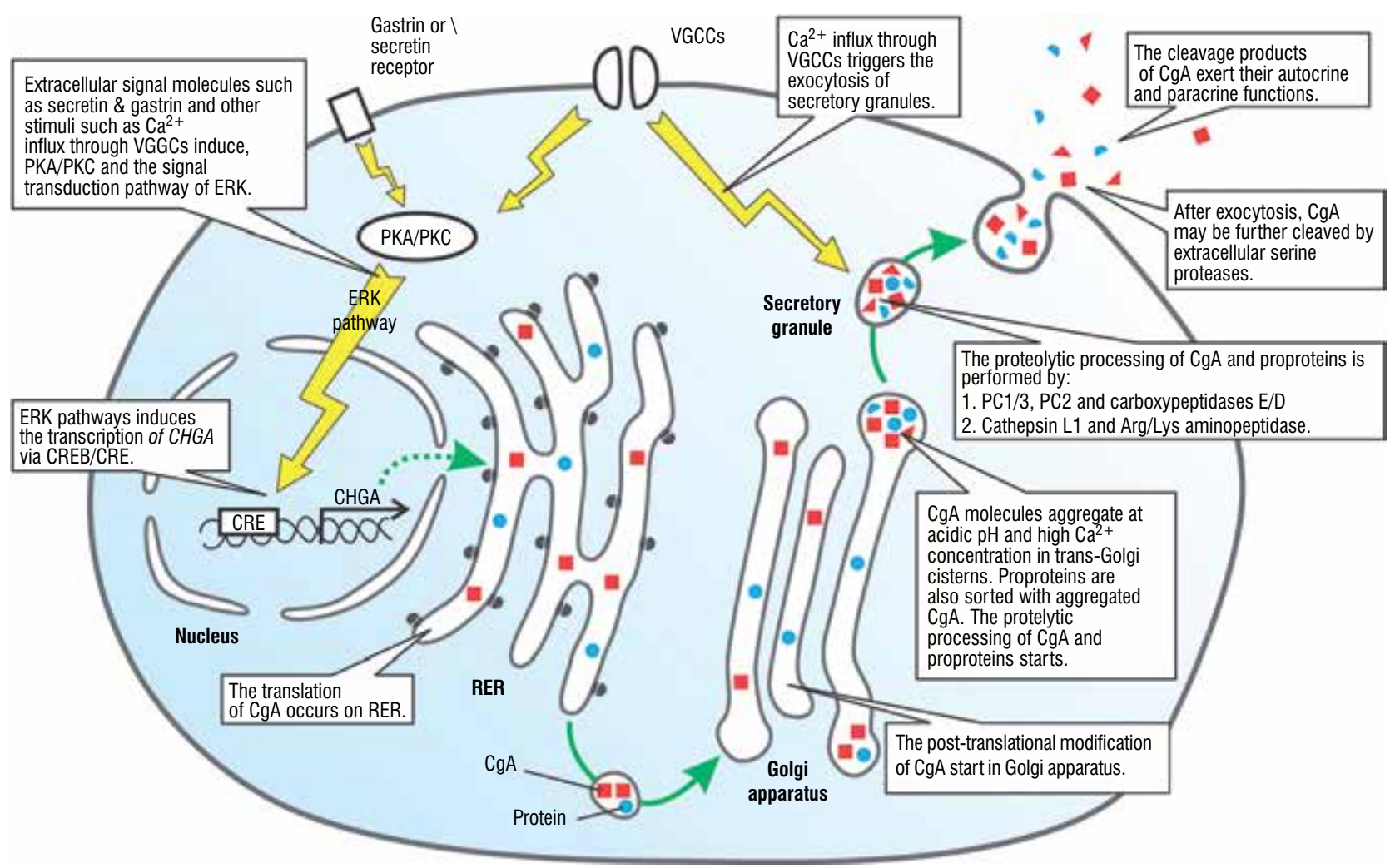

Figure 2. The gene expression, post-translational modification, secretion, and functions of chromogranin $A$. $C g A-\operatorname{chromogranin}$ A; CHGA - CgA gene; CRE - cAMP response element; CREB - cAMP response element-binding protein; ERK - extracellular signal-regulated kinase; $P C 1 / 3$ and $P C 2$ - proprotein convertases $1 / 3$ and $2 ; P K A / P K C$ - protein kinase $A$ and $C ; R E R$ - rough endoplasmic reticulum; VGCCs - voltage-gated $\mathrm{Ca}^{2+}$ channels

Rycina 2. Ekspresja genu, modyfikacja potranslacyjna, wydzielanie i funkcje chromograniny A. CgA - chromogranina A; CHGA gen CgA; CRE (cAMP response element) — element odpowiedzi na cAMP; CREB (cAMP response element-binding protein) — biatko wiążace element odpowiedzi na cAMP; ERK (extracellular signal-regulated kinase) — kinaza regulowana zewnątrzkomórkowo; PC1/3 and PC2 (proprotein convertases $1 / 3$ and 2) - konwertazy proproteinowe $1 / 3$ i 2; PKA/PKC (protein kinase A and C) - kinaza A i C; RER (rough endoplasmic reticulum) — retikulum endoplazmatyczne szorstkie; VGCCs (voltage-gated Ca2+ channels) — kanaty wapniowe potencjałozależne

induced T-cell proliferation and increased cytotoxic activity. The same could not be observed in healthy controls nor in HLA-A*0201-negative T1DM patients.

\section{Chromogranin A in type 2 diabetes mellitus}

Both the salivary and serum levels of $\mathrm{CgA}$ were significantly higher in T2DM patients than in healthy control subjects, and higher $\mathrm{CgA}$ concentrations were more frequently observed in the poorly controlled patients. Furthermore, a significantly higher number of various periodontal diseases occurred in both the well- and poorly-controlled diabetic groups with higher CgA levels [111]. Impaired salivary flow was correlated with significantly higher salivary and serum $\mathrm{CgA}$ levels. Two genetic variants of CHGA (rs9658635 and rs9658655) were associated with lower salivary flow and higher salivary CgA concentrations in T2DM [112].
CHGA knockout (CgA-KO) mice are obese on normal chow diet [113], have significantly higher glucosestimulated insulin secretion after glucose administration [114], have hypertension with higher catecholamine levels [113], and have insulin resistance in muscle cells [115]. Lower triglyceride levels have been found in CgA-KO mice, despite similar amounts of fatty tissue [116].

\section{The role of pancreastatin in the carbohydrate metabolism, in gestational and type 2 diabetes mellitus}

PST is a negative regulator of insulin sensitivity and glucose homeostasis: Hyperglycaemia (a high glucose level in blood) can be at least partly promoted by the PST-mediated inhibition of insulin secretion. In addition, PST also increases blood glucose levels by reducing the hepatic glucose uptake through the inhibition of the insulin-stimulated glycogenesis in primary hepatocytes, 
decreasing the insulin-stimulated synthesis of lipids, and regulating the expression and secretion of leptin in adipocytes $[38,39,117,118]$. In hepatocytes and adipocytes, this is mediated by the G-protein activated phospholipase $C \beta 3$ isoforms (PLC- $\beta 3$ ). PLC- $\beta 3$ causes a cytosolic increase of intracellular $\mathrm{Ca}^{2+}$ ion concentration through inositol trisphosphate signalling, and the promotion of phosphokinase $\mathrm{C}$ (PKC) and mitogen-activated protein kinase pathways [119-122]. Several studies suggest that the insulin inhibition by PST in hepatocytes is also carried out through the activation of the nitric oxide (NO) pathways. NO has a known inhibitory function on insulin [123], while PST can increase NO production [114, 124].

The euglycemic state of the CgA-KO mice is maintained by the increased liver insulin sensitivity. Euglycaemia can be inhibited by the suppression of phosphoenolpyruvate carboxykinase (PEPC) and glucose-6-phosphatase (G6Pase) mRNAs, which leads to hypoglycaemia. Even in the absence of PEPC and G6Pase mRNAs, euglycaemia emerged with the administration of external PST. In hepatocytes transfected with the G6Pase promoter fused with a luciferase reporter, the external PST induced an approximately six-fold transcriptional activation in a PKC- and NO synthetase-dependent manner, which ultimately suppresses insulin signalling [114].

PST influences the physiological homeostasis of blood glucose and insulin in humans. Fasting PST levels of T2DM patients have no significant difference compared to those of control subjects, but postprandial PST concentrations are significantly higher in T2DM patients during an oral glucose tolerance test (OGTT) [125]. The PST hypersecretion in pancreatic cells of T2DM patients may be due to the inhibition of the glucose-induced insulin secretion, ultimately resulting in hyperglycaemia [126]. PST levels of obese T2DM patients are significantly higher compared to those in non-diabetic obese patients and healthy control subjects. After a two-month supervised weight loss, PST concentrations did not change in these groups [127]. Like in T2DM patients, non-obese, essential hypertension patients with pre-diabetic symptoms (hyperinsulinemia or glucose-intolerance) had significantly increased postprandial PST levels during OGTT [128]. An increase (approximately one and a half-fold) in PST serum level was found in GDM patients, and a positive correlation between different catecholamines (epinephrine, norepinephrine) and PST levels was also observed [129].

\section{The presumed role of catestatin in carbohydrate metabolism}

Concerning diabetes and carbohydrate metabolism, in the case of CST, only indirect correlations are available. Some authors assume that the peptide may contribute to the development of metabolic syndrome and diabetes mellitus. Its possible use as a future treatment for obesity and hypertension was also considered [130].

The bodyweight of obese CgA-KO mice [113] can be reduced to that of wild-type mice by administering external CST. The obesity-reducing effects are due to inhibition of alpha $a_{2}$-adrenergic receptor signalling and the enhancement of leptin receptor signalling [131].

CgA-KO mice have been shown to have hypertension, diminished baroreflex sensitivity, and increased catecholamine secretion. By external administration of CST, catecholamine levels and baroreceptor functions can be normalised to wild type values [132].

In the pathomechanism of the obesity-induced insulin resistance and the consequential T2DM, the activation of hepatic Kupffer cells and monocyte-derived recruited macrophages have a crucial effect. $\mathrm{CgA}-\mathrm{KO}$ mice were fed on a high-fat diet to create diet-induced obesity. Mice had elevated insulin and blood glucose levels, compared to wild type mice. External CST treatment normalised the glucose metabolism of hepatocytes and improved the insulin sensitivity of the mice by decreasing various circulating and hepatic lipid fractions, inflammatory cytokines, and via proinflammatory gene expression of hepatic Kupffer cells and macrophages. CST also had direct anti-inflammatory effects, decreasing macrophage activation and recruitment to the liver [133].

\section{Conclusions}

$\mathrm{CgA}$ is produced by various endocrine and neuroendocrine cell types of the different organs, where it plays an important role in the intracellular storage and selective secretion of various hormone peptides in the human body. During and after its secretion, it is cleaved, modified, and converted into biologically active extracellular peptide forms. The CgA cleavage products, such as WE-14, pancreastatin, and catestatin, all have significant and specific biological effects.

Recent studies suggest that the cleavage products of $\mathrm{CgA}$ contribute to the development of different diabetes mellitus forms. WE-14 fulfils a function as an autoantigen for both the diabetogenic, pancreatic beta cell-destroying $\mathrm{CD}^{+}$and $\mathrm{CD}^{+} \mathrm{T}$ cell populations in humans and in a NOD mouse model. CST and PST have regulator roles in T2DM and GDM.

Based on the impact of the currently available knowledge, and the wide range of functions of $\mathrm{CgA}$-derived peptides, further studies are needed to investigate the possible treatment options and the relationships between diabetes mellitus, $\mathrm{CgA}$, and its cleavage products.

\section{Acknowledgements}

We are grateful to Mark Eyre for English proofreading. 
Information on grants and other funding sources

Research was supported by the Wörwag Research Prize for PhD students, announced by Wörwag Pharma Kft. (Hungary), by the grant from the National Research, Development and Innovation Office (NRDIO, project number: K-116128) and by the Research Grant of Hungarian Diabetes Association. Marton Doleschall is supported by Janos Bolyai Research Scholarship of Hungarian Academy of Sciences and STIA-KF-17 grant of Semmelweis University.

\section{References}

1. American Diabetes Association. Diagnosis and classification of diabetes mellitus. Diabetes Care. 2014; 37 Suppl 1: S81-S90, doi: 10.2337/dc14-S081, indexed in Pubmed: 24357215.

2. Ogurtsova K, da Rocha Fernandes JD, Huang Y, et al. IDF Diabetes Atlas: Global estimates for the prevalence of diabetes for 2015 and 2040. Diabetes Res Clin Pract. 2017; 128: 40-50, doi: 10.1016/j.diabres.2017.03.024, indexed in Pubmed: 28437734.

3. Al-Aissa Z, Hadarits $\mathrm{O}$, Rosta $\mathrm{K}$, et al. [A brief of gestational diabetes mellitus, risk factors and current criteria of diagnosis]. Orv Hetil. 2017; 158(8): 283-290, doi: 10.1556/650.2017.30651, indexed in Pubmed: 28218564 .

4. Paschou SA, Papadopoulou-Marketou N, Chrousos GP, et al. On type 1 diabetes mellitus pathogenesis. Endocr Connect. 2018; 7(1): R38-R46, doi: 10.1530/EC-17-0347, indexed in Pubmed: 29191919.

5. Stumvoll M, Goldstein BJ, van Haeften TW. Type 2 diabetes: principle of pathogenesis and therapy. Lancet. 2005; 365(9467): 1333-1346, doi: 10.1016/S0140-6736(05)61032-X, indexed in Pubmed: 15823385.

6. Xie F, Chan JCn, Ma RCw. Precision medicine in diabetes prevention, classification and management. J Diabetes Investig. 2018 [Epub ahead of print], doi: 10.1111/jdi.12830, indexed in Pubmed: 29499103.

7. Forouhi NG, Wareham NJ. Epidemiology of diabetes. Medicine (Abingdon). 2014; 42(12): 698-702, doi: 10.1016/j.mpmed.2014.09.007, indexed in Pubmed: 25568613

8. Ramachandran A, Snehalatha C, Nanditha A. Classification and Diagnosis of Diabetes. In: Holt RIG, Cockram CS, Flyvbjerg A. ed. Textbook of Diabetes. JohnWiley \& Sons Ltd, Chichester 2017: 23-28.

9. Alshiekh S, Larsson H, Ivarsson SA, et al. Autoimmune Type 1 Diabetes. Textbook of Diabetes. 2016: 143-153, doi: 10.1002/9781118924853.ch10.

10. Lukács K, Pánczél P, Hosszúfalusi N. [Genetics of type 1 diabetes: present and future]. Orv Hetil. 2017; 158(44): 1731-1740, doi 10.1556/650.2017.30903, indexed in Pubmed: 29086595.

11. Stadinski BD, Delong T, Reisdorph N, et al. Chromogranin A is an autoantigen in type 1 diabetes. Nat Immunol. 2010; 11(3): 225-231, doi: 10.1038/ni.1844, indexed in Pubmed: 20139986.

12. Gillespie KM. Type 1 diabetes: pathogenesis and prevention. CMAJ. 2006; 175(2): 165-170, doi: 10.1503/cmaj.060244, indexed in Pubmed: 16847277.

13. Kis J, Engelmann P, Heyam J, et al. [The possibility of immunological prevention in type 1 diabetes mellitus] [Hungarian]. Lege Artis Medicinæ. 2006; 16: 771-773.

14. Tsai S, Shameli A, Santamaria P. CD8+ T cells in type 1 diabetes. Adv Immunol. 2008; 100: 79-124, doi: 10.1016/S0065-2776(08)00804-3, indexed in Pubmed: 19111164.

15. Prasad RB, Groop L. Genetic Architecture of Type 2 Diabetes. In: Holt RIG, Cockram CS, Flyvbjerg A. ed. Textbook of Diabetes. JohnWiley \& Sons Ltd, Chichester 2017: 187-204.

16. Reaven GM, Reaven GM. Banting lecture 1988. Role of insulin resistance in human disease. Diabetes. 1988; 37(12): 1595-1607, doi: 10.2337/ diab.37.12.1595, indexed in Pubmed: 3056758.

17. Ricci G, Pirillo I, Tomassoni D, et al. Metabolic syndrome, hypertension, and nervous system injury: Epidemiological correlates. Clin Exp Hypertens. 2017; 39(1): 8-16, doi: 10.1080/10641963.2016.1210629, indexed in Pubmed: 28071980.

18. Olokoba AB, Obateru OA, Olokoba LB. Type 2 diabetes mellitus: a review of current trends. Oman Med J. 2012; 27(4): 269-273, doi: 10.5001/ omj.2012.68, indexed in Pubmed: 23071876.

19. Federation ID. IDF Diabetes Atlas, 8th ed. Brussels, Belgium, 2017. International Diabetes Federation. http://www.diabetesatlas.org (November 14, 2017).

20. Gestational Diabetes Mellitus. Diabetes Care. 2003; 26(Supplement 1) S103-S105, doi: 10.2337/diacare.26.2007.s103.

21. Konecki DS, Benedum UM, Gerdes HH, et al. The primary structure of human chromogranin A and pancreastatin. J Biol Chem. 1987 ; 262(35): 17026-17030, indexed in Pubmed: 2445752.
22. Broedbaek K, Hilsted L. Chromogranin A as biomarker in diabetes. Biomark Med. 2016; 10(11): 1181-1189, doi: 10.2217/bmm-2016-0091, indexed in Pubmed: 27611656

23. Angeletti RH, Hickey WF. A neuroendocrine marker in tissues of the immune system. Science. 1985; 230(4721): 89-90, indexed in Pubmed: 3898368.

24. Nolan JA, Trojanowski JQ, Hogue-Angeletti R. Neurons and neuroendocrine cells contain chromogranin: detection of the molecule in normal bovine tissues by immunochemical and immunohistochemical methods J Histochem Cytochem. 1985; 33(8): 791-798, doi: 10.1177/33.8.3894497, indexed in Pubmed: 3894497.

25. Louthan O. Chromogranin a in physiology and oncology. Folia Biol (Praha). 2011; 57(5): 173-181, indexed in Pubmed: 22123459.

26. Nobels FR, Kwekkeboom DJ, Bouillon R, et al. Chromogranin A: its clinical value as marker of neuroendocrine tumours. Eur J Clin Invest. 1998; 28(6): 431-440, indexed in Pubmed: 9693933.

27. Taupenot L, Harper KL, O'Connor DT. The chromogranin-secretogranin family. N Engl J Med. 2003; 348(12): 1134-1149, doi: 10.1056/NEJMra021405, indexed in Pubmed: 12646671.

28. Vinik AI, Silva MP, Woltering EA, et al. Biochemical testing for neuroendocrine tumors. Pancreas. 2009; 38(8): 876-889, doi: 10.1097/ MPA.0b013e3181bc0e77, indexed in Pubmed: 19855234.

29. Wassberg E, Stridsberg M, Christofferson R. Plasma levels of chromogra$\operatorname{nin} \mathrm{A}$ are directly proportional to tumour burden in neuroblastoma. J Endocrinol. 1996; 151(2): 225-230, indexed in Pubmed: 8958782.

30. Eriksson B, Öberg K, Stridsberg M. Tumor Markers in Neuroendocrine Tumors. Digestion. 2000; 62(1): 33-38, doi: 10.1159/000051853.

31. Telega A, Kos-Kudła B, Foltyn W, et al. Selected neuroendocrine tumour markers, growth factors and their receptors in typical and atypical bronchopulmonary carcinoids. Endokrynol Pol. 2012; 63(6): 477-482, indexed in Pubmed: 23339006.

32. Woliński K, Kaznowski J, Klimowicz A, et al. Diagnostic value of selected biochemical markers in the detection of recurrence of medullary thyroid cancer - comparison of calcitonin, procalcitonin, chromogranin A, and carcinoembryonic antigen. Endokrynol Pol. 2017; 68(4): 434-437, doi: 10.5603/EP.a2017.0038, indexed in Pubmed: 28585679.

33. Marotta V, Zatelli MC, Sciammarella C, et al. Chromogranin A as circulating marker for diagnosis and management of neuroendocrine neoplasms: more flaws than fame. Endocr Relat Cancer. 2018; 25(1): R11-R29, doi: 10.1530/ERC-17-0269, indexed in Pubmed: 29066503.

34. Guillemot J, Guérin M, Thouënnon E, et al. Characterization and plasma measurement of the WE-14 peptide in patients with pheochromocytoma. PLoS One. 2014; 9(2): e88698, doi: 10.1371/journal.pone.0088698, indexed in Pubmed: 24523932.

35. Blaschko H, Comline RS, Schneider FH, et al. Secretion of a chromaffin granule protein, chromogranin, from the adrenal gland after splanchnic stimulation. Nature. 1967; 215(5096): 58-59, doi: 10.1038/215058a0, indexed in Pubmed: 6053402.

36. Banks P, Helle K. The release of protein from the stimulated adrenal medulla. Biochem J. 1965; 97(3): 40C-41C, indexed in Pubmed: 5881651.

37. Gut P, Czarnywojtek A, Fischbach J, et al. Chromogranin A - unspecific neuroendocrine marker. Clinical utility and potential diagnostic pitfalls. Arch Med Sci. 2016; 12(1): 1-9, doi: 10.5114/aoms.2016.57577, indexed in Pubmed: 26925113.

38. Tatemoto K, Efendić S, Mutt V, et al. Pancreastatin, a novel pancreatic peptide that inhibits insulin secretion. Nature. 1986; 324(6096): 476-478, doi: 10.1038/324476a0, indexed in Pubmed: 3537810

39. Schmidt WE, Creutzfeldt W. Pancreastatin - a novel regulatory peptide? Acta Oncol. 1991; 30(4): 441-449, doi: 10.3109/02841869109092399, indexed in Pubmed: 1854501.

40. Drees B, Hamilton J. Pancreastatin and bovine parathyroid cell secretion Bone Miner. 1992; 17(3): 335-346, doi: 10.1016/0169-6009(92)90784-b.

41. Curry WJ, Shaw C, Johnston CF, et al. Isolation and primary structure of a novel chromogranin A-derived peptide, WE-14, from a human midgut carcinoid tumour. FEBS Lett. 1992; 301(3): 319-321, doi: 10.1016/00145793(92)80266-J, indexed in Pubmed: 1577173.

42. Gleeson CM, Curry WJ, Johnston CF, et al. Occurrence of WE-14 and chromogranin A-derived peptides in tissues of the human and bovine gastro-entero-pancreatic system and in human neuroendocrine neoplasia. J Endocrinol. 1996; 151(3): 409-420, doi: 10.1677/joe.0.1510409, indexed in Pubmed: 8994386.

43. Barkatullah SC, Pogue KM, Depreitere J, et al. Immunohistochemical localization of WE-14 in the developing porcine sympathoadrenal cell lineage. Histochem Cell Biol. 2001; 116(3): 255-262, doi: 10.1007/ s004180100315, indexed in Pubmed: 11685555.

44. Mahata SK, O'Connor DT, Mahata M, et al. Novel autocrine feedback control of catecholamine release. A discrete chromogranin a fragment is a noncompetitive nicotinic cholinergic antagonist. J Clin Invest. 1997; 100(6): 1623-1633, doi: 10.1172/JCI119686, indexed in Pubmed: 9294131.

45. Mahata SK, Mahapatra NR, Mahata M, et al. Catecholamine secretory vesicle stimulus-transcription coupling in vivo. Demonstration by a novel transgenic promoter/photoprotein reporter and inhibition of secretion and transcription by the chromogranin A fragment catestatin. J Biol Chem. 2003; 278(34) 32058-32067, doi: 10.1074/jbc.M305545200, indexed in Pubmed: 12799369. 
46. Modi WS, Levine MA, Seuanez HN, et al. The human chromogranin A gene: chromosome assignment and RFLP analysis. Am J Hum Genet. 1989; 45(5): 814-818, indexed in Pubmed: 2573279.

47. Mouland AJ, Bevan S, White JH, et al. Human chromogranin A gene. Molecular cloning, structural analysis, and neuroendocrine cell-specific expression. J Biol Chem. 1994; 269(9): 6918-6926, indexed in Pubmed: 8120054.

48. Murray SS, Deaven LL, Burton DW, et al. The gene for human chromogranin A (CgA) is located on chromosome 14. Biochem Biophys Res Commun. 1987; 142(1): 141-146, indexed in Pubmed: 3814131.

49. Simon JP, Aunis D. Biochemistry of the chromogranin A protein family. Biochem J. 1989; 262(1): 1-13, doi: 10.1042/bj2620001, indexed in Pubmed: 2684154

50. Reiffen FU, Gratzl M. Chromogranins, widespread in endocrine and nervous tissue, bind Ca2+. FEBS Lett. 1986; 195(1-2): 327-330, indexed in Pubmed: 3943617

51. Videen JS, Mezger MS, Chang YM, et al. Calcium and catecholamine interactions with adrenal chromogranins. Comparison of driving forces in binding and aggregation. J Biol Chem. 1992; 267(5): 3066-3073, indexed in Pubmed: 1737762 .

52. Helle K, Metz-Boutigue M, Aunis D. Chromogranin A as a CalciumBinding Precursor for a Multitude of Regulatory Peptides for the Immune, Endocrine and Metabolic Systems. Current Medicinal ChemistryImmunology, Endocrine \& Metabolic Agents. 2001; 1(2): 119-140, doi: 10.2174/1568013013359087.

53. Wu HJ, Rozansky DJ, Parmer RJ, et al. Structure and function of the chromogranin A gene. Clues to evolution and tissue-specific expression. J Biol Chem. 1991; 266(20): 13130-13134, indexed in Pubmed: 2071596.

54. Hendy GN, Bevan S, Mattei MG, et al. Chromogranin A. Clin Invest Med. 1995; 18(1): 47-65, indexed in Pubmed: 7768066.

55. Benedum UM, Baeuerle PA, Konecki DS, et al. The primary structure of bovine chromogranin A: a representative of a class of acidic secretory proteins common to a variety of peptidergic cells. EMBO J. 1986; 5(7): 1495-1502, indexed in Pubmed: 3755681.

56. Parmer RJ, Koop AH, Handa MT, et al. Molecular cloning of chromogranin A from rat pheochromocytoma cells. Hypertension. 1989; 14(4): 435-444, indexed in Pubmed: 2793216.

57. Montero-Hadjadje M, Vaingankar S, Elias S, et al. Chromogranins A and $\mathrm{B}$ and secretogranin II: evolutionary and functional aspects. Acta Physiol (Oxf). 2008; 192(2): 309-324, doi: 10.1111/j.1748-1716.2007.01806.x, indexed in Pubmed: 18005393.

58. Winkler H, Fischer-Colbrie R. The chromogranins A and B: the first 25 years and future perspectives. Neuroscience. 1992; 49(3): 497-528, doi: 10.1016/0306-4522(92)90222-N, indexed in Pubmed: 1501763.

59. Facer P, Bishop AE, Cole GA, et al. Developmental profile of chromogranin, hormonal peptides, and 5-hydroxytryptamine in gastrointestinal endocrine cells. Gastroenterology. 1989; 97(1): 48-57, indexed in Pubmed: 2721879 .

60. Helman LJ, Ahn TG, Levine MA, et al. Molecular cloning and primary structure of human chromogranin A (secretory protein I) cDNA. J Biol Chem. 1988; 263(23): 11559-11563, indexed in Pubmed: 3403545.

61. Molenaar WM, Lee VM, Trojanowski JQ. Early fetal acquisition of the chromaffin and neuronal immunophenotype by human adrenal medullary cells. An immunohistological study using monoclonal antibodies to chromogranin A, synaptophysin, tyrosine hydroxylase, and neuronal cytoskeletal proteins. Exp Neurol. 1990; 108(1): 1-9, indexed in Pubmed: 1969355.

62. Banks P, Helle KB, Mayor D. Evidence for the presence of a chromogranin-like protein in bovine splenic nerve granules. Mol Pharmacol. 1969; 5(2): 210-212, indexed in Pubmed: 5787086.

63. Buffa R, Gini A, Pelagi M, et al. Immunoreactivity of hormonally-characterized human endocrine cells against three novel anti-human chromogranin B(B11 and B13) and chromogranin A (A11) monoclonal antibodies. Arch Histol Cytol. 1989; 52 Suppl: 99-105, indexed in Pubmed: 2510809.

64. Lauweryns JM, van Ranst L, Lloyd RV, et al. Chromogranin in bronchopulmonary neuroendocrine cells. Immunocytochemical detection in human, monkey, and pig respiratory mucosa. J Histochem Cytochem. 1987; 35(1): 113-118, doi: 10.1177/35.1.3098831, indexed in Pubmed: 3098831.

65. Helle KB, Corti A, Metz-Boutigue MH, et al. The endocrine role for chromogranin A: a prohormone for peptides with regulatory properties. Cell Mol Life Sci. 2007; 64(22): 2863-2886, doi: 10.1007/s00018-007-7254-0, indexed in Pubmed: 17717629

66. Saruta J, Tsukinoki K, Sasaguri K, et al. Expression and localization of chromogranin A gene and protein in human submandibular gland. Cells Tissues Organs. 2005; 180(4): 237-244, doi: 10.1159/000088939, indexed in Pubmed: 16330879 .

67. Cramer T, Jüttner S, Plath T, et al. Gastrin transactivates the chromogranin A gene through MEK-1/ERK- and PKC-dependent phosphorylation of Sp1 and CREB. Cell Signal. 2008; 20(1): 60-72, doi: 10.1016/j.cellsig.2007.08.016, indexed in Pubmed: 17889508

68. Mahapatra NR, Mahata M, O'Connor DT, et al. Secretin activation of chromogranin A gene transcription. Identification of the signaling pathways in cis and in trans. J Biol Chem. 2003; 278(22): 19986-19994, doi: 10.1074/jbc.M207983200, indexed in Pubmed: 12646581.
69. Anouar Y, Benie T, De Monti M, et al. Estradiol negatively regulates secretogranin II and chromogranin A messenger ribonucleic acid levels in the female rat pituitary but not in the adrenal. Endocrinology. 1991; 129(5): 2393-2399, doi: 10.1210/endo-129-5-2393, indexed in Pubmed: 1935773.

70. Anouar Y, Duval J. Direct estradiol down-regulation of secretogranin II and chromogranin A mRNA levels in rat pituitary cells. Mol Cell Endocrinol. 1992; 88(1-3): 97-104, indexed in Pubmed: 1281127.

71. Takiyyuddin MA, Neumann HP, Cervenka JH, et al. Ultradian variations of chromogranin A in humans. Am J Physiol. 1991; 261(4 Pt 2): R939-R944, doi: 10.1152/ajpregu.1991.261.4.R939, indexed in Pubmed: 1681748 .

72. Galindo E, Bader MF, Aunis D. Regulation of chromogranin a and chromogranin B (secretogranin I) synthesis in bovine cultured chromaffin cells. J Neuroendocrinol. 1991; 3(6): 669-677, doi: 10.1111/j.13652826.1991.tb00332.x, indexed in Pubmed: 19215537.

73. Simon JP, Bader MF, Aunis D. Effect of secretagogues on chromogranin A synthesis in bovine cultured chromaffin cells. Possible regulation by protein kinase C. Biochem J. 1989; 260(3): 915-922, doi: 10.1042/bj2600915, indexed in Pubmed: 2764913.

74. Kim T, Tao-Cheng JH, Eiden LE, et al. Chromogranin A, an "on/off” switch controlling dense-core secretory granule biogenesis. Cell. 2001; 106(4): 499-509, indexed in Pubmed: 11525735.

75. Gorr SU, Dean WL, Radley TL, et al. Calcium-binding and aggregation properties of parathyroid secretory protein-I (chromogranin A). Bone Miner. 1988; 4(1): 17-25, indexed in Pubmed: 3142532

76. Yoo SH, Lewis MS. Effects of $\mathrm{pH}$ and $\mathrm{Ca} 2+$ on monomer-dimer and monomer-tetramer equilibria of chromogranin A. J Biol Chem. 1992; 267(16): 11236-11241, indexed in Pubmed: 1597459.

77. Settleman J, Nolan J, Angeletti RH. Chromogranin, an integral membrane protein. J Biol Chem. 1985; 260(3): 1641-1644, indexed in Pubmed: 3881436.

78. Westermann R, Stögbauer F, Unsicker K, et al. Calcium-dependence of chromogranin A-catecholamine interaction. FEBS Lett. 1988; 239(2): 203-206, indexed in Pubmed: 3181426.

79. Gorr SU, Shioi J, Cohn DV. Interaction of calcium with porcine adrenal chromogranin A (secretory protein-I) and chromogranin B (secretogranin I). Am J Physiol. 1989; 257(2 Pt 1): E247-E254, doi: 10.1152/ ajpendo.1989.257.2.E247, indexed in Pubmed: 2764102.

80. Seidah NG, Hendy GN, Hamelin J, et al. Chromogranin A can act as a reversible processing enzyme inhibitor. Evidence from the inhibition of the IRCM-serine protease 1 cleavage of pro-enkephalin and ACTH at pairs of basic amino acids. FEBS Lett. 1987; 211(2): 144-150, doi: 10.1016/0014-5793(87)81425-4, indexed in Pubmed: 3026846.

81. Huttner WB, Natori S. Regulated secretion. Helper proteins for neuroendocrine secretion. Curr Biol. 1995; 5(3): 242-245, indexed in Pubmed: 7780730.

82. Kiang WL, Krusius T, Finne J, et al. Glycoproteins and proteoglycans of the chromaffin granule matrix. J Biol Chem. 1982; 257(4): 1651-1659, indexed in Pubmed: 7056734.

83. Bhargava G, Russell J, Sherwood LM. Phosphorylation of parathyroid secretory protein. Proc Natl Acad Sci U S A. 1983; 80(3): 878-881, indexed in Pubmed: 6572375.

84. Gorr SU, Hamilton JW, Cohn DV, et al. Secretion of sulfated and nonsulfated forms of parathyroid chromogranin A (secretory protein-I). J Biol Chem. 1990; 265(6): 3012-3016, indexed in Pubmed: 2105940.

85. Nguyen MH, Harbour D, Gagnon C. Secretory proteins from adrenal medullary cells are carboxyl-methylated in vivo and released under their methylated form by acetylcholine. J Neurochem. 1987; 49(1): 38-44, indexed in Pubmed: 3585340.

86. Sigafoos J, Chestnut WG, Merrill BM, et al. Novel peptides from adrenomedullary chromaffin vesicles. J Anat. 1993; 183 ( Pt 2): 253-264, indexed in Pubmed: 8300415.

87. Eskeland NL, Zhou A, Dinh TQ, et al. Chromogranin A processing and secretion: specific role of endogenous and exogenous prohormone convertases in the regulated secretory pathway. J Clin Invest. 1996; 98(1): 148-156, doi: 10.1172/JCI118760, indexed in Pubmed: 8690787.

88. Biswas N, Rodriguez-Flores JL, Courel M, et al. Cathepsin L colocalizes with chromogranin a in chromaffin vesicles to generate active peptides. Endocrinology. 2009; 150(8): 3547-3557, doi: 10.1210/en.2008-1613, indexed in Pubmed: 19372204.

89. Hook V, Yasothornsrikul S, Greenbaum D, et al. Cathepsin L and Arg/ Lys aminopeptidase: a distinct prohormone processing pathway for the biosynthesis of peptide neurotransmitters and hormones. Biol Chem. 2004; 385(6): 473-480, doi: 10.1515/BC.2004.055, indexed in Pubmed: 15255178.

90. Benedum UM, Lamouroux A, Konecki DS, et al. The primary structure of human secretogranin I (chromogranin B): comparison with chromogranin A reveals homologous terminal domains and a large intervening variable region. EMBO J. 1987; 6(5): 1203-1211, indexed in Pubmed: 3608978 .

91. Thiele C, Huttner WB. The disulfide-bonded loop of chromogranins, which is essential for sorting to secretory granules, mediates homodimerization. J Biol Chem. 1998; 273(2): 1223-1231, indexed in Pubmed: 9422790. 
92. Rouillé Y, Duguay SJ, Lund K, et al. Proteolytic processing mechanisms in the biosynthesis of neuroendocrine peptides: the subtilisin-like proprotein convertases. Front Neuroendocrinol. 1995; 16(4): 322-361, doi: 10.1006/frne.1995.1012, indexed in Pubmed: 8557169.

93. Prigge ST, Mains RE, Eipper BA, et al. New insights into copper monooxygenases and peptide amidation: structure, mechanism and function. Cell Mol Life Sci. 2000; 57(8-9): 1236-1259, indexed in Pubmed: 11028916.

94. Metz-Boutigue MH, Garcia-Sablone P, Hogue-Angeletti R, et al. Intracellular and extracellular processing of chromogranin A. Determination of cleavage sites. Eur J Biochem. 1993; 217(1): 247-257, indexed in Pubmed: 8223562.

95. Jiang $Q$, Taupenot L, Mahata SK, et al. Proteolytic cleavage of chromogranin A (CgA) by plasmin. Selective liberation of a specific bioactive $\mathrm{CgA}$ fragment that regulates catecholamine release. J Biol Chem. 2001; 276(27): 25022-25029, doi: 10.1074/jbc.M101545200, indexed in Pubmed: 11342539

96. Parmer RJ, Mahata M, Gong Y, et al. Processing of chromogranin A by plasmin provides a novel mechanism for regulating catecholamine secretion. J Clin Invest. 2000; 106(7): 907-915, doi: 10.1172/JCI7394, indexed in Pubmed: 11018079.

97. Crippa L, Bianco M, Colombo B, et al. A new chromogranin Adependent angiogenic switch activated by thrombin. Blood. 2013 121(2): 392-402, doi: 10.1182/blood-2012-05-430314, indexed in Pubmed: 23190532.

98. Curry WJ, Johnston CF, Hutton JC, et al. The tissue distribution of rat chromogranin A-derived peptides: evidence for differential tissue processing from sequence specific antisera. Histochemistry. 1991; 96(6): 531-538, indexed in Pubmed: 1769862

99. Portela-Gomes GM, Stridsberg M. Selective processing of chromogranin A in the different islet cells in human pancreas. J Histochem Cytochem. 2001; 49(4): 483-490, doi: 10.1177/002215540104900408, indexed in Pubmed: 11259451 .

100. Portela-Gomes GM, Stridsberg M. Chromogranin A in the human gastrointestinal tract: an immunocytochemical study with regionspecific antibodies. J Histochem Cytochem. 2002; 50(11): 1487-1492, doi 10.1177/002215540205001108, indexed in Pubmed: 12417614.

101. Baker RL, Bradley B, Wiles TA, et al. Cutting Edge: Nonobese Diabetic Mice Deficient in Chromogranin A Are Protected from Autoimmune Diabetes. J Immunol. 2016; 196(1): 39-43, doi: 10.4049/jimmunol.1501190, indexed in Pubmed: 26608914.

102. Li Yi, Zhou L, Li Y, et al. Identification of autoreactive CD8+ T cell responses targeting chromogranin A in humanized NOD mice and type 1 diabetes patients. Clin Immunol. 2015; 159(1): 63-71, doi: 10.1016/j. clim.2015.04.017, indexed in Pubmed: 25958206.

103. Anderson MS, Venanzi ES, Klein L, et al. Projection of an immunological self shadow within the thymus by the aire protein. Science. 2002 298(5597): 1395-1401, doi: 10.1126/science.1075958, indexed in Pubmed 12376594.

104. Delong T, Baker RL, He J, et al. Diabetogenic T-cell clones recognize an altered peptide of chromogranin A. Diabetes. 2012; 61(12): 3239-3246 doi: 10.2337/db12-0112, indexed in Pubmed: 22912420.

105. Gottlieb PA, Delong T, Baker RL, et al. Chromogranin A is a T cell antigen in human type 1 diabetes. J Autoimmun. 2014; 50: 38-41, doi: 10.1016/j. jaut.2013.10.003, indexed in Pubmed: 24239002.

106. Jin N, Wang Y, Crawford F, et al. N-terminal additions to the WE14 peptide of chromogranin A create strong autoantigen agonists in type 1 diabetes. Proc Natl Acad Sci U S A. 2015; 112(43): 13318-13323, doi 10.1073/pnas.1517862112, indexed in Pubmed: 26453556.

107. Sollid L. Molecular Basis of Celiac Disease. Annu Rev Immunol. 2000; 18(1): 53-81, doi: 10.1146/annurev.immunol.18.1.53

108. Blancou P, Mallone R, Martinuzzi E, et al. Immunization of HLA class transgenic mice identifies autoantigenic epitopes eliciting dominant responses in type 1 diabetes patients. J Immunol. 2007; 178(11): 7458-7466, indexed in Pubmed: 17513797.

109. Serreze DV, Marron MP, Dilorenzo TP. „Humanized” HLA transgenic NOD mice to identify pancreatic beta cell autoantigens of potential clinical relevance to type 1 diabetes. Ann N Y Acad Sci. 2007; 1103: 103-111, doi: 10.1196/annals.1394.019, indexed in Pubmed: 17376821.

110. Takaki T, Marron MP, Mathews CE, et al. HLA-A*0201-restricted T cells from humanized NOD mice recognize autoantigens of potential clinical relevance to type 1 diabetes. J Immunol. 2006; 176(5): 3257-3265, indexed in Pubmed: 16493087.

111. Kogawa EM, Grisi DC, Falcão DP, et al. Impact of glycemic control on oral health status in type 2 diabetes individuals and its association with salivary and plasma levels of chromogranin A. Arch Oral Biol. 2016; 62: 10-19, doi: 10.1016/j.archoralbio.2015.11.005, indexed in Pubmed: 26605682.

112. Kogawa EM, Grisi DC, Falcão DP, et al. Salivary function impairment in type 2 Diabetes patients associated with concentration and genetic polymorphisms of chromogranin A. Clin Oral Investig. 2016; 20(8) 2083-2095, doi: 10.1007/s00784-015-1705-z, indexed in Pubmed: 26750135.
113. Mahapatra NR, O'Connor DT, Vaingankar SM, et al. Hypertension from targeted ablation of chromogranin A can be rescued by the human ortholog. J Clin Invest. 2005; 115(7): 1942-1952, doi: 10.1172/JCI24354, indexed in Pubmed: 16007257.

114. Gayen JR, Saberi M, SchenkS, et al. A novel pathway of insulin sensitivity in chromogranin A null mice: a crucial role for pancreastatin in glucose homeostasis. J Biol Chem. 2009; 284(42): 28498-28509, doi: 10.1074/jbc M109.020636, indexed in Pubmed: 19706599.

115. Tang K, Pasqua T, Biswas A, et al. Muscle injury, impaired muscle function and insulin resistance in Chromogranin A-knockout mice. J Endocrinol. 2017; 232(2): 137-153, doi: 10.1530/JOE-16-0370, indexed in Pubmed: 27799464

116. Bandyopadhyay GK, Vu CU, Gentile S, et al. Catestatin (chromogranin A(352-372)) and novel effects on mobilization of fat from adipose tissue through regulation of adrenergic and leptin signaling. J Biol Chem. 2012; 287(27): 23141-23151, doi: 10.1074/jbc.M111.335877, indexed in Pubmed: 22535963.

117. González-Yanes C, Sánchez-Margalet V. Pancreastatin, a chromogranin A-derived peptide, inhibits leptin and enhances UCP-2 expression in isolated rat adipocytes. Cell Mol Life Sci. 2003; 60(12): 2749-2756, doi: 10.1007/s00018-003-3346-7, indexed in Pubmed: 14685697.

118. Sánchez V, Lucas M, Calvo JR, et al. Glycogenolytic effect of pancreastatin in isolated rat hepatocytes is mediated by a cyclic-AMP-independen $\mathrm{Ca}(2+)$-dependent mechanism. Biochem J. 1992; 284 ( Pt 3): 659-662, doi: 10.1042/bj2840659, indexed in Pubmed: 1377910.

119. Ahrén B, Bertrand G, Roye M, et al. Pancreastatin modulates glucosestimulated insulin secretion from the perfused rat pancreas. Acta Physio Scand. 1996; 158(1): 63-70, doi: 10.1046/j.1365-201X.1996.525291000.x, indexed in Pubmed: 8876749.

120. Sanchez V, Calvo JR, Goberna R. Glycogenolytic effect of pancreastatin in the rat. Biosci Rep. 1990; 10(1): 87-91, doi: 10.1007/BF01116856, indexed in Pubmed: 2187544

121. Sánchez-Margalet V, González-Yanes C, Najib S, et al. Metabolic effects and mechanism of action of the chromogranin A-derived peptide pancreastatin. Regul Pept. 2010; 161(1-3): 8-14, doi: 10.1016/j.regpep.2010.02.005, indexed in Pubmed: 20184923.

122. Valicherla GR, Hossain Z, Mahata SK, et al. Pancreastatin is an endogenous peptide that regulates glucose homeostasis. Physiol Genomics. 2013; 45(22): 1060-1071, doi: 10.1152/physiolgenomics.00131.2013, indexed in Pubmed: 24064537.

123. Mosén $\mathrm{H}$, Salehi A, Henningsson R, et al. Nitric oxide inhibits, and carbon monoxide activates, islet acid alpha-glucoside hydrolase activities in parallel with glucose-stimulated insulin secretion. J Endocrinol. 2006; 190(3): 681-693, doi: 10.1677/joe.1.06890, indexed in Pubmed: 17003269.

124. Sánchez-Margalet V, González-Yanes C, Najib S. Pancreastatin, a chromogranin A-derived peptide, inhibits DNA and protein synthesis by producing nitric oxide in HTC rat hepatoma cells. J Hepatol. 2001; 35(1) 80-85, doi: 10.1016/S0168-8278(01)00071-X, indexed in Pubmed: 11495046.

125. Tateishi K, Funakoshi A, Wakasugi H, et al. Plasma pancreastatin-like immunoreactivity in various diseases. J Clin Endocrinol Metab. 1989 69(6): 1305-1308, doi: 10.1210/jcem-69-6-1305, indexed in Pubmed: 2555388

126. Funakoshi A, Tateishi K, Shinozaki H, et al. Elevated plasma levels of pancreastatin (PST) in patients with non-insulin-dependent diabetes mellitus (NIDDM). Regul Pept. 1990; 30(2): 159-164, doi: 10.1016/01670115(90)90056-3, indexed in Pubmed: 2274680.

127. O'Connor DT, Cadman PE, Smiley C, et al. Pancreastatin: multiple actions on human intermediary metabolism in vivo, variation in disease, and naturally occurring functional genetic polymorphism. J Clin Endocrinol Metab. 2005; 90(9): 5414-5425, doi: 10.1210/jc.2005-0408, indexed in Pubmed: 15956083.

128. Sánchez-Margalet V, Valle M, Lobón JA, et al. Increased plasma pancreastatin-like immunoreactivity levels in non-obese patients with essential hypertension. J Hypertens. 1995; 13(2): 251-258, doi: 10.1097/00004872199502000-00013, indexed in Pubmed: 7615956.

129. Sánchez-Margalet V, Lobón JA, González A, et al. Increased plasma pancreastatin-like levels in gestational diabetes: correlation with catecholamine levels. Diabetes Care. 1998; 21(11): 1951-1954, doi: 10.2337/ diacare.21.11.1951, indexed in Pubmed: 9802749.

130. Ying W, Mahata S, Bandyopadhyay GK, et al. Chromogranin A Regulation of Obesity and Peripheral Insulin Sensitivity. Front Endocrinol (Lausanne). 2017; 8(5): 20-848, doi: 10.3389/fendo.2017.00020, indexed in Pubmed: 28228748

131. Kim SJ, Tang T, Abbott M, et al. AMPK Phosphorylates Desnutrin/ATGL and Hormone-Sensitive Lipase To Regulate Lipolysis and Fatty Acid Oxidation within Adipose Tissue. Mol Cell Biol. 2016; 36(14): 1961-1976, doi: 10.1128/MCB.00244-16, indexed in Pubmed: 27185873

132. Gayen JR, Gu Y, O'Connor DT, et al. Global disturbances in autonomic function yield cardiovascular instability and hypertension in the chromogranin a null mouse. Endocrinology. 2009; 150(11): 5027-5035, doi: 10.1210/en.2009-0429, indexed in Pubmed: 19819970. 
133. Ying W, Mahata S, Bandyopadhyay GK, et al. Catestatin Inhibits Obesity-Induced Macrophage Infiltration and Inflammation in the Liver and Suppresses Hepatic Glucose Production, Leading to Improved Insulin Sensitivity. Diabetes. 2018; 67(5): 841-848, doi: 10.2337/db17-0788, indexed in Pubmed: 29432123.

134. Degorce F, Goumon Y, Jacquemart L, et al. A new human chromogranin A (CgA) immunoradiometric assay involving monoclonal antibodies raised against the unprocessed central domain (145-245). Br J Cancer. 1999; 79(1): 65-71, doi: 10.1038/sj.bjc.6690013, indexed in Pubmed: 10408695.

135. Stridsberg M, Eriksson B, Oberg K, et al. A comparison between three commercial kits for chromogranin A measurements. J Endocrinol. 2003; 177(2): 337-341, indexed in Pubmed: 12740022.

136. Soell M, Feki A, Hannig M, et al. Chromogranin A detection in saliva of type 2 diabetes patients. Bosn J Basic Med Sci. 2010; 10(1): 2-8, doi: 10.17305/bjbms.2010.2725, indexed in Pubmed: 20192923.

137. Stridsberg M. Measurements of chromogranins and chromogranin-related peptides by immunological methods. Adv Exp Med Biol. 2000; 482: 319-327, doi: 10.1007/0-306-46837-9 25, indexed in Pubmed: 11192592.

138. Pregun I, Herszényi L, Juhász M, et al. Effect of proton-pump inhibitor therapy on serum chromogranin a level. Digestion. 2011; 84(1): 22-28, doi: 10.1159/000321535, indexed in Pubmed: 21304238.

139. Glinicki P, Jeske W. Chromogranin A $(\mathrm{CgA})$ - the influence of various factors in vivo and in vitro, and existing disorders on it's concentration in blood. Endokrynol Pol. 2010; 61(4): 384-387, indexed in Pubmed: 20806183.

140. Goetze JP, Alehagen U, Flyvbjerg A, et al. Chromogranin A as a biomarker in cardiovascular disease. Biomark Med. 2014; 8(1): 133-140, doi: 10.2217/ bmm.13.102, indexed in Pubmed: 24325234.

141. Kollipara S. Comorbidities associated with type 1 diabetes. School Nurse News. 2006; 23(4): 42-45, indexed in Pubmed: 17017044

142. Glinicki P, Jeske W, Kapuścińska R, et al. Comparison of chromogranin $\mathrm{A}(\mathrm{CgA})$ levels in serum and plasma (EDTA2K) and the respective reference ranges in healthy males. Endokrynol Pol. 2015; 66(1): 53-56, doi: 10.5603/EP.2015.0009, indexed in Pubmed: 25754282

143. Glinicki P,Kapuścińska R, Jeske W. The differences in chromogranin A(CgA) concentrations measured in serum and in plasma by IRMA and ELISA methods. Endokrynol Pol. 2010; 61(4): 346-350, indexed in Pubmed: 20806177.

144. Tsao KC, Wu JT. Development of an ELISA for the detection of serum chromogranin $\mathrm{A}(\mathrm{CgA})$ in prostate and non-neuroendocrine carcinomas. Clin Chim Acta. 2001; 313(1-2): 21-29, indexed in Pubmed: 11694235.

145. Popovici T, Moreira B, Schlageter MH, et al. Automated two-site immunofluorescent assay for the measurement of serum chromogranin A. Clin Biochem. 2014; 47(1-2): 87-91, doi: 10.1016/j.clinbiochem.2013.10.029, indexed in Pubmed: 24201067.

146. van der Knaap RHP, Kwekkeboom DJ, Ramakers CRB, et al. Evaluation of a new immunoassay for chromogranin A measurement on the Kryptor system. Pract Lab Med. 2015; 1: 5-11, doi: 10.1016/j.plabm.2015.03.002, indexed in Pubmed: 28932793.

147. Ferrero S, Buffa R, Pruneri G, et al. The prevalence and clinical significance of chromogranin A and secretogranin II immunoreactivity in colorectal adenocarcinomas. Virchows Arch. 1995; 426(6): 587-592, indexed in Pubmed: 7655739

148. Huegel R, Velasco P, De la Luz Sierra M, et al. Novel anti-inflammatory properties of the angiogenesis inhibitor vasostatin. J Invest Dermatol. 2007; 127(1): 65-74, doi: 10.1038/sj.jid.5700484, indexed in Pubmed: 16888632.

149. Xiong W, Wang X, Dai $D$, et al. The anti-inflammatory vasostatin-2 attenuates atherosclerosis in ApoE mice and inhibits monocyte/macrophage recruitment. Thromb Haemost. 2017; 117(2): 401-414, doi: 10.1160/ TH16-06-0475, indexed in Pubmed: 27831589.

150. Lugardon K, Raffner R, Goumon Y, et al. Antibacterial and antifungal activities of vasostatin-1, the N-terminal fragment of chromogranin A. J Biol Chem. 2000; 275(15): 10745-10753, indexed in Pubmed: 10753865.

151. Helle KB, Metz-Boutigue MH, Cerra MC, et al. Chromogranins: from discovery to current times. Pflugers Arch. 2018; 470(1): 143-154, doi: 10.1007/s00424-017-2027-6, indexed in Pubmed: 28875377.

152. Aardal S, Helle KB. The vasoinhibitory activity of bovine chromogranin A fragment (vasostatin) and its independence of extracellular calcium in isolated segments of human blood vessels. Regul Pept. 1992; 41(1): 9-18, doi: 10.1016/0167-0115(92)90509-S, indexed in Pubmed: 1455014.

153. Drees BM, Rouse J, Johnson J, et al. Bovine parathyroid glands secrete a 26-kDa N-terminal fragment of chromogranin-A which inhibits parathyroid cell secretion. Endocrinology. 1991; 129(6): 3381-3387, doi: 10.1210/endo-129-6-3381, indexed in Pubmed: 1954912

154. Lugardon K, Chasserot-Golaz S, Kieffer AE, et al. Structural and biological characterization of chromofungin, the antifungal chromogranin A-(47-66)-derived peptide. J Biol Chem. 2001; 276(38): 35875-35882, doi: 10.1074/jbc.M104670200, indexed in Pubmed: 11451958.

155. Zhang D, Shooshtarizadeh P, Laventie BJ, et al. Two chromogranin a-derived peptides induce calcium entry in human neutrophils by calmodulin-regulated calcium independent phospholipase A2. PLoS One. 2009; 4(2): e4501, doi: 10.1371/journal.pone.0004501, indexed in Pubmed: 19225567.
156. Salem S, Jankowski V, Asare $Y$, et al. Identification of the Vasoconstriction-Inhibiting Factor (VIF), a Potent Endogenous Cofactor of Angiotensin II Acting on the Angiotensin II Type 2 Receptor. Circulation. 2015; 131(16): 1426-1434, doi: 10.1161/CIRCULATIONAHA.114.013168, indexed in Pubmed: 25810338.

157. Galindo E, Rill A, Bader MF, et al. Chromostatin, a 20-amino acid peptide derived from chromogranin A, inhibits chromaffin cell secretion. Proc Natl Acad Sci U S A. 1991; 88(4): 1426-1430, doi: 10.1073/ pnas.88.4.1426, indexed in Pubmed: 1996343.

158. Strub JM, Goumon Y, Lugardon K, et al. Antibacterial activity of glycosylated and phosphorylated chromogranin A-derived peptide 173-194 from bovine adrenal medullary chromaffin granules. J Biol Chem. 1996; 271(45): 28533-28540, indexed in Pubmed: 8910482.

159. Gayen JR, Zhang K, RamachandraRao SP, et al. Role of reactive oxygen species in hyperadrenergic hypertension: biochemical, physiological, and pharmacological evidence from targeted ablation of the chromogranin a (Chga) gene. Circ Cardiovasc Genet. 2010, 3(5): 414-425, doi: 10.1161/CIRCGENETICS.109.924050, indexed in Pubmed: 20729505.

160. Bandyopadhyay GK, Lu M, Avolio E, et al. Pancreastatin-dependent inflammatory signaling mediates obesity-induced insulin resistance. Diabetes. 2015; 64(1): 104-116, doi: 10.2337/db13-1747, indexed in Pubmed: 25048197.

161. Cadman PE, Rao F, Mahata SK, et al. Studies of the dysglycemic peptide, pancreastatin, using a human forearm model. Ann N Y Acad Sci. 2002; 971: 528-529, indexed in Pubmed: 12438174.

162. Aslam R, Marban C, Corazzol C, et al. Cateslytin, a chromogranin A derived peptide is active against Staphylococcus aureus and resistant to degradation by its proteases. PLoS One. 2013; 8(7): e68993, doi: 10.1371/ journal.pone.0068993, indexed in Pubmed: 23894389.

163. Zaet A, Dartevelle P, Daouad F, et al. D-Cateslytin, a new antimicrobia peptide with therapeutic potential. Sci Rep. 2017; 7(1): 15199, doi: 10.1038/s41598-017-15436-z, indexed in Pubmed: 29123174.

164. Briolat J, Wu SD, Mahata SK, et al. New antimicrobial activity for the catecholamine release-inhibitory peptide from chromogranin A. Cell Mol Life Sci. 2005; 62(3): 377-385, doi: 10.1007/s00018-004-4461-9, indexed in Pubmed: 15723172.

165. O'Connor DT, Kailasam MT, Kennedy BP, et al. Early decline in the catecholamine release-inhibitory peptide catestatin in humans at genetic risk of hypertension. J Hypertens. 2002; 20(7): 1335-1345, indexed in Pubmed: 12131530.

166. Angelone T, Quintieri AM, Brar BK, et al. The antihypertensive chromogranin a peptide catestatin acts as a novel endocrine/paracrine modulator of cardiac inotropism and lusitropism. Endocrinology. 2008; 149(10): 4780-4793, doi: 10.1210/en.2008-0318, indexed in Pubmed: 18535098

167. Bassino E, Fornero S, Gallo MP, et al. A novel catestatin-induced antiadrenergic mechanism triggered by the endothelial PI3K-eNOS pathway in the myocardium. Cardiovasc Res. 2011; 91(4): 617-624, doi: 10.1093/cvr/cvr129, indexed in Pubmed: 21543385.

168. Theurl M, Schgoer W, Albrecht K, et al. The neuropeptide catestatin acts as a novel angiogenic cytokine via a basic fibroblast growth factordependent mechanism. Circ Res. 2010; 107(11): 1326-1335, doi: 10.1161/ CIRCRESAHA.110.219493, indexed in Pubmed: 20930149.

169. Mohseni S, Emtenani S, Emtenani S, et al. Antioxidant properties of a human neuropeptide and its protective effect on free radical-induced DNA damage. J Pept Sci. 2014; 20(6): 429-437, doi: 10.1002/psc.2634, indexed in Pubmed: 24723458.

170. Fasciotto BH, Denny JC, Greeley GH, et al. Processing of chromogranin $\mathrm{A}$ in the parathyroid: generation of parastatin-related peptides. Peptides. 2000; 21(9): 1389-1401, indexed in Pubmed: 11072127.

171. Fasciotto BH, Trauss CA, Greeley GH, et al. Parastatin (porcine chromogranin A347-419), a novel chromogranin A-derived peptide, inhibits parathyroid cell secretion. Endocrinology. 1993; 133(2): 461-466, doi: 10.1210/endo.133.2.8344192, indexed in Pubmed: 8344192.

172. Kirchmair R, Leitner B, Fischer-Colbrie R, et al. Large variations in the proteolytic formation of a chromogranin A-derived peptide (GE-25) in neuroendocrine tissues. Biochem J. 1995; 310 ( Pt 1): 331-336, indexed in Pubmed: 7646465.

173. Lorenz K, Gramlich OW, Grus FH, et al. GE-25-like immunoreactivity in the rat eye. Peptides. 2012; 36(2): 286-291, doi: 10.1016/j.peptides.2012.04.022, indexed in Pubmed: 22634234.

174. Loh YP, Koshimizu H, Cawley NX, et al. Serpinins: role in granule biogenesis, inhibition of cell death and cardiac function. Curr Med Chem. 2012; 19(24): 4086-4092, indexed in Pubmed: 22834799.

175. Tota B, Gentile S, Pasqua T, et al. The novel chromogranin A-derived serpinin and pyroglutaminated serpinin peptides are positive cardiac $\beta$-adrenergic-like inotropes. FASEB J. 2012; 26(7): 2888-2898, doi: 10.1096/fj.11-201111, indexed in Pubmed: 22459152. 